\title{
The Impact of Intellectual Capital on Corporate Performance of IT Companies: Evidence from Bursa Istanbul
}

\author{
Sedeaq Nassar \\ Islamic University of Gaza \\ Gaza, Palestine \\ Email: stnassar@iugaza.edu.ps
}

Received June, 2018; September, 2018

\begin{abstract}
This study aimed to investigate the impact of intellectual capital (IC) on corporate performance of IT companies listed on Borsa Istanbul for the period of 2004-2015. Value Added Intellectual Coefficient (VAIC) approach was applied to measure Intellectual Capital Efficiency (ICE). Corporate performance was calculated using traditional accounting tools involving; Market, Productivity, and Financial performance. The findings showed that human capital efficiency is the most effective factor in the issue of value creation than structural capital and capital employed for the study period before and after the crisis 2008. Structural capital efficiency does not play a considerable role in value creation before and after the crisis. While Capital employed efficiency was not considered as an engine to value creation before the crisis, but it played a key role in value creation after the crisis.
\end{abstract}

Keywords: Intellectual capital; Human capital; Structural capital; Capital employed; Value added intellectual coefficient.

Type: Research paper

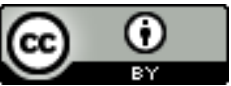

This work is licensed under a Creative Commons Attribution 4.0 International License.

\section{DOI: 10.51325/ijbeg.v1i3.17}

\section{Introduction}

The growing focus on knowledge and knowledge-based economy as a result of the information technology revolution has led to a steady increase in interest of the Intellectual Capital (IC). Therefore, in knowledge based-economy and ultra-competitive era, where organizations are facing a constantly changing environment, organizations have to shift from relying on traditional assets (tangible assets) to depends on intellectual assets (intangible assets). Pulic (2000); Roos et al. (1997); Stewart (1997); Sullivan (1999) defined IC as the organization's intellectual potential, that specifying the efficiency degree of the use of physical capital and intellectual properties in adding value of the organization. According to (Pulic, 2000a), IC can be divided into three main components; Human Capital (HC), Structural Capital (SC), and Capital Employed (CE).

$\mathrm{HC}$ is the most important part of Intellectual Capital, as it is considered the key role of competitiveness, innovation, and value creation for what it includes of employees skills and qualifications that the organization would lose if these employees decided to leave (Chang, 2010; Edvinsson \& Malone, 1997; Muhammad \& Ismail, 2009; Sullivan, 1999). It is the invested value in the employees' knowledge, skills, and experiences, training and 
development, wages and salaries of individual workers ((Pulic, 2000a). SC, on the other hand, is the non-human part of intellectual assets that remains after employees decide to leave the organization (Al-Zoubi, 2013; Chen, et. al., 2005). It is information and technology, databases and organizational structures that help organizations to function (Bontis, 1998). The third component of IC is the CE which is the tangible part of capital, that cover both physical and financial assets (Pulic, 2004).

The main purpose of this study is to examine the relationship between intellectual capital and firm performance of IT companies listed on Borsa Istanbul before and after the financial crisis. The broad area of study, under which the paper falls in, is the area of market, productivity, and financial performance within the Intellectual Capital context.

\section{Literature Review}

The value added intellectual coefficient (VAIC), the key method of this study, has been created and developed by Ante Pulic (1998-2000) in cooperation with his colleagues at the Austrian intellectual capital research Centre (AICRS) (Abdulsalam, Al-Qaheri, \& AlKhayyat, 2011; Chen Goh, 2005). The VAIC model measures the intellectual capital efficiency of an organization and produces an evident index through allocated the clear economic values such as value added (VA), human capital efficiency (HCE), structural capital efficiency (SCE), and capital employed efficiency (CEE) (Iazzolino \& Laise, 2013).

The VAIC model is a widely applied by researchers from many countries to investigate the IC efficiency for banking, industrial, and other sectors (Abdulsalam et al., 2011). For instance, Pulic (2000); Bozbura (2004); Mavridis (2004); Li and Wu (2004); Chen et al. (2005); Mavridis and Kyrmizoglou (2005); Yu et al. (2010); Zeghal and Maaloul (2010); Jafari (2013); Nassar (2018) found that IC has totally or partially a significant positive relationships with firm's market performance. Whereas, The VAIC model is a widely applied by researchers from many countries to investigate the IC efficiency for banking, industrial, and other sectors (Abdulsalam et al., 2011). For instance, Pulic (2000); Bozbura (2004); Mavridis (2004); Li and Wu (2004); Chen et al. (2005); Mavridis and Kyrmizoglou (2005); (Yu et al., 2010, 2010); Zeghal and Maaloul (2010); Jafari (2013); Nassar, (2018) found that IC has totally or partially a significant positive relationships with firm's market performance. Whereas, Dženopoljac, Janoševic, \& Bontis (2016); Firer \& Williams (2003); Maditinos, Chatzoudes, Tsairidis, \& Theriou (2011); Mehralian, Rasekh, Akhavan, \& Sadeh (2012); Tan, Plowman, \& Hancock (2007); Avci \& Nassar (2017) found a negative relationship between IC and market performance or no relationship between them. The findings of first hypothesis $\mathrm{H} 1$ should support or reject the results of earlier studies in terms of the presence of a relationship between IC and company's market performance that benchmarked by market to book (MB) ratio and priceearnings (PE) ratio. 
$H_{1}:$ There is a significant positive association between Value Added Intellectual Capital (VAIC) and its components (HCE, SCE and CEE) and company's market performance (MB, PE).

On the other hand, several researchers have been examined the relationship between IC and company's productivity performance which represented by Asset Turnover (ATO) ratio. Many of them such Chen et al. (2005); Mavridis and Kyrmizoglou (2005); Kamath (2008); Hang Chan (2009b); Mondal and Ghosh (2012) found a significant positive association between IC and productivity performance. Some other Firer and Williams (2003); (Yu et al., 2010, 2010); (Wang, 2011); Clarke et al. (2011); (Komnenic \& Pokrajčić, 2012); Mehralian et al. (2012); Bontis et al. (2015); Dženopoljac et al. (2016); Linda et.al. (2018) did not find an impact of IC on productivity performance. The results of second hypothesis $\mathrm{H} 2$ should support or reject the results of earlier studies in terms of the existence of a relationship between IC and company's productivity performance represented by Asset Turnover (ATO) ratio.

$\mathrm{H}_{2}:$ There is a significant positive association between Value Added Intellectual Capital (VAIC) and its components (HCE, SCE and CEE) and company's productivity performance (ATO).

The last, about the relationship between IC and company's financial performance which utilized by return on assets (ROA), return on equity (ROE), and earnings per share (EPS), many studies indicated a significant positive influence of IC on company's financial performance. These studies like Pulic (2000); (Riahi-Belkaoui, 2003); Bozbura (2004); Li and Wu (2004); Mavridis (2004); Chen et al. (2005); Mavridis and Kyrmizoglou (2005); Hang Chan (2009b); Rehman et al. (2012); Jafari (2013). On the other side, a limited number of researchers such as Firer and Williams (2003); Tan et al. (2007); Yu et al. (2010); Maditinos et al. (2011); Mehralian et al. (2012); Dženopoljac et al. (2016) found a negative impact of IC on financial performance of the companies. The findings of third hypothesis H3 should support or reject the results of earlier studies in terms of the existence of a relationship between IC and company's financial performance that benchmarked by return on assets (ROA), return on equity (ROE), and earnings per share (EPS).

H3: $_{3}$ There is a significant positive association between Value Added Intellectual Capital (VAIC) and its components (HCE, SCE and CEE) and company's financial performance (ROA, ROE, and EPS).

\section{Methodology and Data}

To examine the relationship between intellectual capital and company's performance, financial data for IT companies listed on Borsa Istanbul between 2004 and 2015 was collected from the FINNET database and their financial statements. Firms with missing data and discontinuous listing were excluded from the sample. The study period is divided into two periods; pre-crisis period over 2004-2007, and post-crisis period over 2010-2015. 
Intellectual capital is measured using Pulic's Value Added Intellectual Coefficient (VAIC) model. The VAIC is the sum of its three components; human capital efficiency (HCE), structural capital efficiency (SCE), and capital employed efficiency (CEE).

$$
\mathrm{VAIC}=\mathrm{HCE}+\mathrm{SCE}+\mathrm{CEE}
$$

The dependent variables of the study are Market, Productivity, and Financial performance. Market performance represented by market to book ratio (MB) and price to earnings ratio (PE), productivity performance measured by assets turnover ratio (ATO), and financial performance represented by return on assets (ROA), return on equity (ROE), and earning per share (EPS) ratios, in addition to some control variables. A detailed list of the study variables is presented in the table 1 .

The study uses the linear regression model (OLS) to find and to compare the impact of IC (independent variables) on firm's performance (dependent variables) between two periods; before the crisis period (2004-2007) and after the crisis period (2010-2015).

Table 1: Summary of Variables

\begin{tabular}{|l|l|}
\hline \multicolumn{2}{|l|}{ Independent Variables } \\
\hline $\begin{array}{l}\text { Value Added Intellectual Capital } \\
\text { (VAIC) }\end{array}$ & VAIC = HCE + SCE + CEE \\
\hline Human Capital Efficiency (HCE) & HCE = Value added / Human Capital \\
\hline Structural Capital Efficiency (SCE) & $\begin{array}{l}\text { Structural Capital / Value Added, where Structural Capital equal Value } \\
\text { Added minus Human Capital. }\end{array}$ \\
\hline Capital Employed Efficiency (CEE) & $\begin{array}{l}\text { Value Added / Capital Employed, where Capital Employed is the sum } \\
\text { of financial and physical capital of the firm. }\end{array}$ \\
\hline Dependent Variables & \multicolumn{2}{|l|}{} \\
\hline Market to Book value (MB) & Market Capitalization/Book Value \\
\hline Price-Earnings ratio (PE) & Market value per share/Earning per share \\
\hline Assets Turnover (ATO) & Total Revenue/Total Book Value \\
\hline Return on Assets (ROA) & Net Income/Total Assets \\
\hline Return on Equity (ROE) & Net Income/Total Equity \\
\hline Earnings per Share (EPS) & (Net Income-Preferred Dividends) / (Average Outstanding Shares) \\
\hline Control Variables & Age of the company from its establishment time \\
\hline Firm Age (FAGE) & Log of a company's total assets \\
\hline Firm Size (FSIZE) & Total debt / Total assets \\
\hline Firm Leverage (FLEV) &
\end{tabular}

The study models are divided into two main models, Model 1 examines the relationship between IC components and firm performance, while Model 2 examines the relationship between VAIC and firm performance. Such models can be writing as follows:

Model $1 Y_{i t}=\beta+\beta_{1} H C E+\beta_{2} S C E+\beta_{3} C E E+\beta_{4} C_{i t}+\varepsilon$ 
Model $2 Y_{i t}=\beta+\beta_{1} V A I C+\beta_{2} C_{i t}+\varepsilon$

\subsection{Descriptive Statistics}

Descriptive statistics of independent, dependent and control variables of 14 sample companies are represented in table 2 shows the descriptive of the study variables for the pre-and post-crisis period.

Table 2 shows that the three components of VAIC (HCE, SCE, and CEE) have a respective mean value of $(4.39,0.74$ and -0.17$)$ before the crisis and a respective mean value of $(4.44,0.86$ and 0.10$)$ after crisis for the IT companies. According to this result, one can say that $\mathrm{HC}$ is the most effective component in the issue of value creation than $\mathrm{SC}$ and $\mathrm{CE}$ for the study period. The market performance variables (MB and PE ratios) do not show any specific trend before and after crisis. Likewise, the productivity ratio (ATO) does not appear any specific trend before and after the crisis. Regarding financial performance ratios (ROA, ROE, and EPS) only ROA ratio shows a good average ranging at $(0.05$ and 0.06$)$ before and after the crisis respectively. Moreover, EPS ratio shows a good average ranging at 0.57 , and 0.41 before and after the crisis respectively. The standard deviation for the independent variables is the highest in HCE and for dependent variables is the highest in PE and ROE ratios. From above explanation, one can say that there are no significant differences in descriptive between the study's variables before and after the crisis.

Table 2: Descriptive statistics

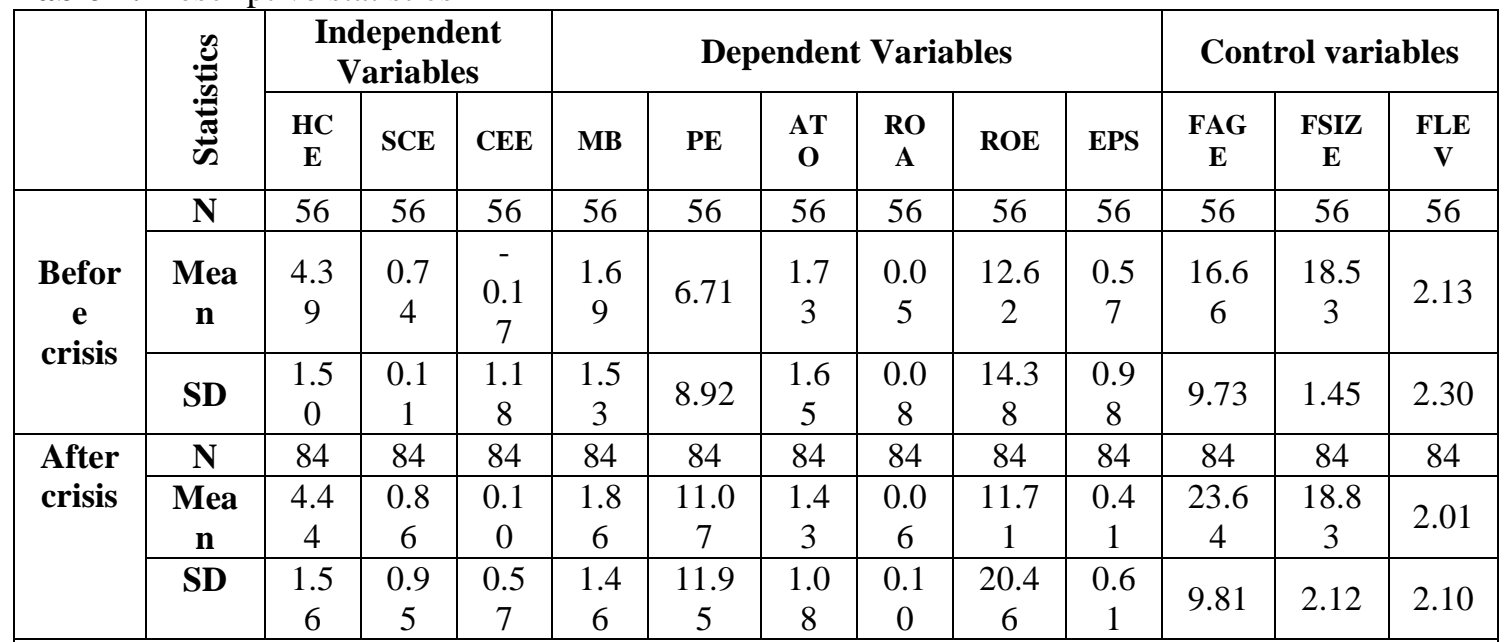

HCE is human capital efficiency, SCE is structural capital efficiency, CEE is capital employed efficiency, MB is market to book ratio, PE is price-earnings ratio, ATO is assets turnover, ROA is return on assets, ROE is return on equity, EPS is earnings per share, FAGE is firm age, FSIZE is firm size, FLEV is firm leverage.

\subsection{Regression analysis}

Table 3 presents the OLS regression statistics among each of dependent, control, and independent variables before and after the financial crisis. Model 1 represents the 
regression statistics between dependent variables and the components of VAIC through control variable. Model 2 depicts the regression statistics between dependent variables and VAIC through control variables.

The results of table 3 shows that VAIC and its components (HCE, SCE and CEE) have no impact on firms' market performance (MB, PE) except HCE which has a significant positive impact on $\mathrm{PE}$ after the crisis. In addition, productivity performance variable (ATO) has no relationship with VAIC and its components before and after the crisis. Moreover, regarding firms' financial performance, the results of table 3 show that, while HCE has a significant negative impact on ROA before the crisis, it has a significant positive impact on ROE and EPS after the crisis. SCE has a significant positive impact on ROA and ROE before the crisis and the same impact on ROA after the crisis. CEE has a significant negative impact on ROE and EPS before the crisis. VAIC has a significant positive impact on ROA and a significant negative impact on EPS before the crisis. After the crisis, it has a significant positive impact on ROA and ROE.

Table 3: Regression analysis

\begin{tabular}{|c|c|c|c|c|c|c|c|c|c|c|c|c|}
\hline \multicolumn{13}{|c|}{ Before Crisis 2004 - 2007} \\
\hline \multirow{2}{*}{ Variables } & \multicolumn{2}{|c|}{ MB } & \multicolumn{2}{|c|}{$\overline{\mathbf{P E}}$} & \multicolumn{2}{|c|}{ ATO } & \multicolumn{2}{|c|}{ ROA } & \multicolumn{2}{|c|}{ ROE } & \multicolumn{2}{|c|}{ EPS } \\
\hline & Model1 & Model2 & Model1 & Model2 & Model1 & Model2 & Model1 & Model2 & Model1 & Model2 & Model1 & Model2 \\
\hline Constant & 2.315 & 4.618 & -19.878 & -18.181 & $\begin{array}{c}- \\
5.922 * * *\end{array}$ & $\begin{array}{c}- \\
6.483 * * * \\
\end{array}$ & $-0.524 * *$ & $-0.720 *$ & $\begin{array}{c}- \\
105.691 *\end{array}$ & $\begin{array}{c}- \\
135.331 *\end{array}$ & $-8.637 *$ & $-10.991^{*}$ \\
\hline \multicolumn{13}{|c|}{ Control variables } \\
\hline FAGE & 0.250 & 0.203 & 0.092 & 0.057 & $-0.456^{*}$ & $-0.435^{*}$ & -0.177 & 0.107 & -0.260 & -0.104 & $0.357 *$ & $0.425^{*}$ \\
\hline FSIZE & -0.115 & -0.197 & 0.232 & 0.293 & $0.433^{*}$ & $0.428 * *$ & $0.631^{*}$ & 0.289 & $0.665 *$ & $0.554 *$ & $0.649 *$ & $0.779 *$ \\
\hline FLEV & $0.359 * *$ & $0.480^{* *}$ & -0.247 & -0.264 & $0.313^{*}$ & $0.300 * *$ & $-0.407 * *$ & $0.282^{-} * * *$ & 0.071 & 0.058 & $0.290 * *$ & $-0.490 *$ \\
\hline \multicolumn{13}{|c|}{ Independent variables } \\
\hline $\mathrm{HCE}$ & 0.180 & & -0.152 & & -0.029 & & $-0.573 * *$ & & -0.337 & & -0.136 & \\
\hline SCE & -0.139 & & -0.057 & & 0.068 & & $1.193 *$ & & $0.612 * *$ & & 0.139 & \\
\hline CEE & 0.268 & & 0.066 & & -0.055 & & -0.139 & & $\stackrel{-}{-}_{0.226^{* * * *}}$ & & $-0.466^{*}$ & \\
\hline VAIC & & 0.085 & & -0.129 & & 0.036 & & $0.323 * *$ & & 0.079 & & $\begin{array}{c}- \\
0.205^{* * *}\end{array}$ \\
\hline F-Stat. & 1.73 & 1.40 & 0.88 & 0.76 & 17.92 & 9.71 & 2.87 & 7.82 & 5.60 & 4.98 & 9.24 & 9.83 \\
\hline Prob.(F) & 0.161 & 0.230 & 0.483 & 0.623 & 0.000 & 0.000 & 0.034 & 0.000 & 0.001 & 0.000 & 0.000 & 0.000 \\
\hline R-square & 0.136 & 0.193 & 0.074 & 0.115 & 0.620 & 0.624 & 0.207 & 0.572 & 0.337 & 0.460 & 0.456 & 0.627 \\
\hline $\begin{array}{c}\text { R-Square } \\
\text { Change }\end{array}$ & & 0.058 & & 0.041 & & 0.004 & & 0.365 & & 0.122 & & 0.170 \\
\hline Obs. & 56 & 56 & 56 & 56 & 56 & 56 & 56 & 56 & 56 & 56 & 56 & 56 \\
\hline \multicolumn{13}{|c|}{ After Crisis 2010 - 2015} \\
\hline \multirow{2}{*}{ Variables } & \multicolumn{2}{|c|}{ MB } & \multicolumn{2}{|c|}{ PE } & \multicolumn{2}{|c|}{ ATO } & \multicolumn{2}{|c|}{ ROA } & \multicolumn{2}{|c|}{ ROE } & \multicolumn{2}{|c|}{ EPS } \\
\hline & Model1 & Model2 & Model1 & Model2 & Model1 & Model2 & Model1 & Model2 & Model1 & Model2 & Model1 & Model2 \\
\hline Constant & $3.529 * *$ & 3.369 & -2.102 & 10.932 & $-5.403 *$ & $-5.264 *$ & 0.068 & 0.022 & -34.199 & -32.314 & -0.962 & -0.555 \\
\hline \multicolumn{13}{|c|}{ Control variables } \\
\hline FAGE & 0.213 & 0.219 & 0.471 & 0.553 & $-0.549 *$ & $-0.518^{*}$ & -0.076 & -0.029 & -0.071 & 0.008 & $0.277 * *$ & $0.360^{*}$ \\
\hline FSIZE & -0.192 & -0.196 & -0.001 & -0.224 & $0.868^{*}$ & $0.803 *$ & 0.016 & -0.038 & $0.303 *$ & 0.153 & 0.192 & -0.002 \\
\hline FLEV & 0.101 & 0.105 & -0.040 & 0.009 & -0.118 & -0.102 & $-0.267 * *$ & $0.242^{* * * *}$ & $-0.444 *$ & $-0.399 *$ & -0.152 & -0.107 \\
\hline $\mathrm{HCE}$ & 0.032 & & $0.261 * *$ & & 0.109 & & 0.202 & & $0.300 *$ & & $0.276^{* * *}$ & \\
\hline SCE & 0.030 & & -0.090 & & 0.042 & & $0.192 * * *$ & & 0.128 & & 0.020 & \\
\hline CEE & 0.016 & & -0.072 & & -0.054 & & -0.018 & & -0.045 & & -0.106 & \\
\hline VAIC & & 0.048 & & 0.116 & & 0.085 & & $0.256^{* *}$ & & $0.283^{*}$ & & 0.177 \\
\hline F-Stat. & 0.68 & 0.40 & 5.90 & 4.13 & 22.13 & 12.80 & 3.67 & 3.23 & 4.63 & 4.18 & 3.97 & 3.15 \\
\hline Prob.(F) & 0.605 & 0.899 & 0.001 & 0.012 & 0.000 & 0.000 & 0.009 & 0.005 & 0.002 & 0.001 & 0.005 & 0.006 \\
\hline R-square & 0.033 & 0.036 & 0.230 & 0.276 & 0.528 & 0.541 & 0.157 & 0.229 & 0.190 & 0.278 & 0.168 & 0.225 \\
\hline $\begin{array}{c}\text { R-Square } \\
\text { Change }\end{array}$ & & 0.002 & & 0.045 & & 0.013 & & 0.073 & & 0.088 & & 0.057 \\
\hline Obs. & 84 & 84 & 84 & 84 & 84 & 84 & 84 & 84 & 84 & 84 & 84 & 84 \\
\hline
\end{tabular}




\section{Conclusion}

Intellectual capital has become the main resource of value creation. it is especially true in knowledge-based economy, such as IT sector, where the value added of companies and individuals has direct association with their knowledge and intellectual capital (Bontis, 2001). The main purpose of this study is to investigate the relationship of intellectual capital and its components (human capital, structural capital, and capital employed) on market, productivity, and financial performance of IT companies listed on Borsa Istanbul before and after the crisis. The paper is conducted by using the data from 14 company's annual reports listed on Borsa Istanbul. Pulic's method VAIC was used as a measurement of intellectual capital, where $\mathrm{MB}$ and $\mathrm{PE}$ ratios used as indicators of market performance, ROA, ROE and EPS ratios used as indicators of financial performance, and ATO ratio is used as indicator of productivity performance. The findings show that HCE is the most effective factor in the issue of value creation than structural capital and capital employed for the study period after the crisis especially with financial measures indicators ROE and EPS. SCE plays a considerable role in value creation before the crisis where has a significant impact on financial performance indicators ROA and ROE. CEE does not consider as an engine to value creation before and after the crisis. This means that the Turkish companies depend on intellectual assets rather than physical assets before and after the crisis. Although, VAIC shows a good association with financial performance of the IT companies before and after the crisis, one can say that Turkish companies still weakly used its intellectual capital to create value.

The findings of the study are consistent with the previous studies e.g. Bontis et al., (2000); Muhammad \& Ismail, (2014); Goh (2005); El-Bannany, (2012); Shih et al., (2010); Mondal \& Ghosh, (2012); Mention \& Bontis, (2013); Joshi et al., (2010); Yalama \& Coskun, (2007). And partly consistent with the previous studies e.g. Holienka \& Pilková, (2014); Sumedrea, (2013) and Radianto, (2011).

This study has limitations due to the lack of data sources, where there are many missing values during the study's period, hence, the external validity was very weak. Therefore, the findings cannot be generalized for other sectors because of the differences in the nature of those sectors.

Suggestions for future research would be applying the study on other sectors, comparing between IT sectors in the region, and comparing between VAIC as measurement of intellectual capital with other measurements of intellectual capital.

\section{References}


Abdulsalam, F., Al-Qaheri, H., \& Al-Khayyat, R. (2011). The Intellectual Capital Performance of KuwaitiBanks: An Application of vaicTM1 Model. IBusiness, 03(01), 88-96. https://doi.org/10.4236/ib.2011.31014

Al-Zoubi, M. R. (2013). The Impact of Intellectual Capital on SWOT Analysis among Jordanian Banking Industry" Empirical Study". International Journal of Business and Social Science, 4(2), 123-137.

Avci, E., \& Nassar, S. (2017). Intellectual capital and its impact on firm performance of the Turkish financial sector before and after financial crisis. PressAcademia Procedia, 3(1), 916-924. https://doi.org/10.17261/Pressacademia.2017.674

Bontis, N. (1998). Intellectual capital: an exploratory study that develops measures and models. Management Decision, 36(2), 63-76. https://doi.org/10.1108/00251749810204142

Bontis, N. (2001). Assessing knowledge assets: a review of the models used to measure intellectual capital. International Journal of Management Reviews, 3(1), 41-60. https://doi.org/10.1111/1468-2370.00053

Bontis, N., Chua Chong Keow, W., \& Richardson, S. (2000). Intellectual capital and business performance in Malaysian industries. Journal of Intellectual Capital, 1(1), 85-100. https://doi.org/10.1108/14691930010324188

Bozbura, F. T. (2004). Measurement and application of intellectual capital in Turkey. The Learning Organization, 11(4/5), 357-367. https://doi.org/10.1108/09696470410538251

Chan, K. H. (2009). Impact of intellectual capital on organisational performance: An empirical study of companies in the Hang Seng Index (Part 2). The Learning Organization, 16(1), 22-39. https://doi.org/10.1108/09696470910927650

Chang, W. S. (2010). The Different Proportion of IC Components and Firms' Market Performance: Evidence from Taiwan. The International Journal of Business and Finance Research, 4(4), 121-134.

Chen Goh, P. (2005). Intellectual capital performance of commercial banks in Malaysia. Journal of Intellectual Capital, 6(3), 385-396. https://doi.org/10.1108/14691930510611120

Chen, M., Cheng, S., \& Hwang, Y. (2005). An empirical investigation of the relationship between intellectual capital and firms' market value and financial performance. Journal of Intellectual Capital, 6(2), 159-176. https://doi.org/10.1108/14691930510592771

Dženopoljac, V., Janoševic, S., \& Bontis, N. (2016). Intellectual capital and financial performance in the Serbian ICT industry. Journal of Intellectual Capital, 17(2), 373396. https://doi.org/10.1108/JIC-07-2015-0068

Edvinsson, L. (1997). Developing intellectual capital at Skandia. Long Range Planning, 30(3), 366-373. https://doi.org/10.1016/S0024-6301(97)90248-X

Edvinsson, L., \& Malone, M. S. (1997). Intellectual Capital: Realizing Your Company's True Value by Finding Its Hidden Brainpower (1st edition). New York: HarperBusiness. 
Firer, S., \& Williams, S. M. (2003). Intellectual capital and traditional measures of corporate performance. Journal of Intellectual Capital, 4(3), 348-360. https://doi.org/10.1108/14691930310487806

Iazzolino, G., \& Laise, D. (2013). Value added intellectual coefficient (VAIC): A methodological and critical review. Journal of Intellectual Capital, 14(4), 547-563. https://doi.org/10.1108/JIC-12-2012-0107

Jafari, E. (2013). Intellectual Capital and its Effects on Firms' market value and Financial Performance in Iran: An Investigating Pulic Model. Research Journal of Recent Sciences, 2(3), 1-6.

Kamath, G. B. (2007). The intellectual capital performance of the Indian banking sector. Journal of Intellectual Capital, 8(1), 96-123. https://doi.org/10.1108/14691930710715088

Kamath, G. B. (2008). Intellectual capital and corporate performance in Indian pharmaceutical industry. Journal of Intellectual Capital, 9(4), 684-704. https://doi.org/10.1108/14691930810913221

Komnenic, B., \& Pokrajčić, D. (2012). Intellectual capital and corporate performance of MNCs in Serbia. Journal of Intellectual Capital, 13(1), 106-119. https://doi.org/10.1108/14691931211196231

Linda, F. ., Rym, T. . and Mounir, K. (2018). The Impact of Governance on the Level of Disclosure and its Role in Attracting and Supporting Foreign Investment: Model of Qatar Stock Exchange, International Journal of Business Ethics and Governance, 1(1), pp. 37-63. https://doi.org/10.51325/ijbeg.v1i1.11

Li, D. Q., \& Wu, X. B. (2004). Empirical study on the linkage of Intellectual Capital and firm Performance. Presented at the Engineering Management Conference, Engineering Management Conference. https://doi.org/10.1109/IEMC.2004.1407188

Maditinos, D., Chatzoudes, D., Tsairidis, C., \& Theriou, G. (2011). The impact of intellectual capital on firms' market value and financial performance. Journal of Intellectual Capital, 12(1), 132-151. https://doi.org/10.1108/14691931111097944

Mavridis, D. G. (2004). The intellectual capital performance of the Japanese banking sector. Journal of Intellectual Capital, 5(1), 92-115. https://doi.org/10.1108/14691930410512941

Mavridis, D. G., \& Kyrmizoglou, P. (2005). Intellectual capital performance drivers in the Greek banking sector. Management Research News, 28(5), 43-62. https://doi.org/10.1108/01409170510629032

Mehralian, G., Rasekh, H. R., Akhavan, P., \& Sadeh, M. R. (2012). The impact of intellectual capital efficiency on market value: An Empirical Study from Iranian Pharmaceutical Companies. Iranian Journal of Pharmaceutical Research, 11(1), 195-207.

Meihami, B., Varmaghani, Z., \& Meihami, H. (2013). Role of Intellectual Capital on Firm Performance (Evidence from Iranian Companies). International Letters of Social and Humanistic Sciences, 12 , 43-50. https://doi.org/10.18052/www.scipress.com/ILSHS.12.43 
Mondal, A., \& Ghosh, S. K. (2012). Intellectual capital and financial performance of Indian banks. Journal of Intellectual Capital, 13(4), 515-530. https://doi.org/10.1108/14691931211276115

Moradi, M., Saeedi, M., Hajizadeh, H., \& Mohammadi, M. (2013). The Influence of Intellectual Capital on the Improvement of Companies' Financial Performance. International Journal of Economics, Business and Finance, 1(5), 120-139.

Muhammad, N. M. N., \& Ismail, M. K. A. (2009). Intellectual capital efficiency and firm's performance: Study on Malaysian financial sectors. International journal of economics and finance, 1(2), 206-212. https://doi.org/10.5539/ijef.v1n2p206

Nassar, S. (2018). The Impact of Intellectual Capital on Firm Performance of the Turkish Real Estate Companies Before and After the Crisis. European Scientific Journal, 14(1). https://doi.org/10.19044/esj.2018.v14n1p29

Pulic, A. (2000). VAIC ${ }^{\mathrm{TM}}$-an accounting tool for IC management. International Journal of Technology Management, 20(5-8), 702-714. https://doi.org/10.1504/IJTM.2000.002891

Pulic, A. (2004). Intellectual capital - does it create or destroy value? Measuring Business Excellence, 8(1), 62-68. https://doi.org/10.1108/13683040410524757

Rehman, W. U., Rehman, H. U., Usman, M., \& Asghar, N. (2012). A Link of intellectual capital performance with corporate performance: comparative study from banking sector in Pakistan. International Journal of Business and Social Science, 3(12).

Riahi-Belkaoui, A. (2003). Intellectual capital and firm performance of US multinational firms: A study of the resource-based and stakeholder views. Journal of Intellectual Capital, 4(2), 215-226. https://doi.org/10.1108/14691930310472839

Roos, G., Roos, J., Dragonetti, N. C., \& Edvinsson, L. (1997). Intellectual Capital: Navigating in the New Business Landscape. London, UK: Macmillan Publications.

Stewart, T. (1997). Intellectual Capital: The New Wealth Of Organizations (illustrated, reprint). Business Digest, New York: Doubleday / Currency. https://doi.org/10.1007/978-1-349-14494-5

Sullivan, P. H. (1999). Profiting from intellectual capital. Journal of Knowledge Management, 3(2), 132-143. https://doi.org/10.1108/13673279910275585

Tan, H. P., Plowman, D., \& Hancock, P. (2007). Intellectual capital and financial returns of companies. Journal of Intellectual Capital, 8(1), 76-95. https://doi.org/10.1108/14691930710715079

Wang, M. S. (2011). Intellectual Capital and Firm Performance. In Annual Conference on Innovations in Business \& Management (pp. 1-26). London, UK.

Yu, K. Y., Ng, H. T., Wong, W. K., Chu, K. W., \& Chan, K. H. (2010). An empirical study of the impact of intellectual capital performance on business performance. In Proceedings of the 7th International Conference on Intellectual Capital Knowledge Management and Organisational Learning, Hong Kong, 11-12

Zeghal, D., \& Maaloul, A. (2010). Analysing value added as an indicator of intellectual capital and its consequences on company performance. Journal of Intellectual Capital, 11(1), 39-60. https://doi.org/10.1108/14691931011013325 
